\section{An Ancestral Habit in a Sea-Urchin}

THE heart-urchin Echinocardium cordatum is one of the most abundant species in the littoral fauna of the British Isles. It is found everywhere where smooth sandy beaches occur and it is distributed all over the bottom of the North Sea to the Danish coast. Its normal mode of life is to excavate a burrow for itself situated about 6 inches below the surface of the sand: this burrow is connected by a vertical shaft with the surface. The roof of the burrow is supported by a cockscomb-like crest of curved spines and the surface of the urchin is quite unpolluted by the sand which forms the wall of the burrow. Through the vertical shaft the urchin pro. trudes the long tube-feet which belong to the anterior ambulacrum : the discs terminating these tube-feet are fringed with fingers so as to resemble small seaanemones and with these the urchin sweeps up small animals lying on the bottom. So effective are they, that where Echinocardium abounds no mussels can exist : for as soon as the young mussels metamorphose from free-swimming larvæ, they are seized by the tube-feet of the buried Echinocardium and conveyed to its mouth.

The heart-urchin is capable of deserting its burrow and moving elsewhere to dig out a fresh one; but, so far as hitherto observed, its movements are carried out by the spines of its under-surface, which are curved and end in spoon-shaped tips: obviously tube-feet could give little support in shifting sand.

The habits of the regular sea-urchin form a complete contrast to those of the heart-urchin. When opportunity is afforded of seeing the regular urchin in its natural surroundings, it is easy to see that it is pre-eminently a climber. It is found clinging to vertical faces of rock; it uses its long tube-feet as cables to pull it forwards whilst it steadies itself with its spines. Gifted with sharp razor-like teeth, it gets its living by scraping the short algal growth from the rocks on which it climbs. In my opinion, this climbing habit explains the evolution of the globular sea-urchin from a flattened starfish-like ancestor.

During a recent visit to Plymouth as a member of the committee which annually inspects the biological station there, I observed a half-grown Echinocardium cordatum confined in a square glass tank with vertical walls. To my amazement I saw that the animal had climbed one of the vertical walls, to which it was clinging by its tube-feet, using these in the same manner as does the regular sea-urchin.

Now all the evidence available points unequivocally to the conclusion that the heart-urchins have sprung from ancestors which, did they live now, would be regarded as regular urchins, so that we find buried deeply in what we may call 'psychic constitution' of the heart-urchin an inherited habit which, in the normal circumstances of its life, can rarely if ever be called into play, but which is nevertheless there and can function if the necessity for it arrives. Truly the inner constitution of this, as of all other animals, is made up of layers of habits !

West Bank,

E. W. MacBride.

Alton,

Hants.

May 22.

\section{Mixed Agglutination}

IF a mixed suspension of sheep erythrocytes and a certain strain of Friedländer bacilli are made to agglutinate in the presence of both homologous antisera, what appears to be a novel form of agglutination -mixed agglutination-is observed. The clumps obtained under our conditions by thus simultaneously mixing two antigens and their antibodies in the same system are seen to consist not only of red cells adherent to red cells, and not only of bacilli adherent to bacilli, but also of bacilli and red cells adherent to one another. Control experiments with only one antiserum do not yield the mixed clumps, although occasionally a red cell or two may be seen adherent to the specifically agglutinated organisms, and vice versa.

It is planned to carry out similar experiments on other systems composed of two or more antigens and their respective anti-sera to ascertain if this phenomenon, as yet observed only in these preliminary experiments, is a general one. If the phenomenon is a general one, and if the point of view be accepted that sensitisation involves more or less of a surface deposit of anti-body globulin, it would appear that under certain conditions the part of the globulin molecule related to its specific properties is unossential for the process of agglutination.

\section{East 68 th Street, New York City.} April 15.

\section{Harold A. Abramson.}

\section{Mechanism of the Pasteur Effect}

THE following recent observations are relevant to the aerobic glycolysis and increased oxygen uptake ${ }^{1}$ caused by addition of potassium salts to glucolysing brain slices, and also to the mechanism of the Pasteur effect.

Potassium chloride causes increased oxygen uptake in brain tissue with substrates other than glucose, for example, fructose and lactate, which cannot form lactic acid in nitrogen. Here no aerobic glycolysis results. Further, the rate of disappearance of lactate $\left(-Q_{\mathrm{L}}^{0_{2}}\right)$ is markedly increased by potassium :

\begin{tabular}{|c|c|c|c|c|}
\hline \multirow[t]{2}{*}{ Substrate } & \multicolumn{2}{|c|}{ Without $M / 10 \mathrm{KCl}$} & \multicolumn{2}{|c|}{ With $M / 10 \mathrm{KCl}$} \\
\hline & $Q_{\mathrm{O}}$ & $Q_{\mathrm{L}}^{\mathbf{O}_{3}}$ & $Q_{\mathrm{O}_{\mathrm{g}}}$ & $Q_{\mathrm{L}}^{\mathrm{O}_{2}}$ \\
\hline $\begin{array}{l}\text { Fructose } \\
0.2 \text { per cent }\end{array}$ & $\begin{array}{l}-6 \cdot 9 \\
-6 \cdot 5\end{array}$ & $\begin{array}{l}+0.2 \\
+0.2\end{array}$ & $\begin{array}{r}-10.5 \\
-\quad 9.2\end{array}$ & $\begin{array}{l}-0.1 \\
-0.65\end{array}$ \\
\hline $\begin{array}{l}\text { Lactate } \\
0.2 \text { per cent }\end{array}$ & $\begin{array}{l}-9 \cdot 2 \\
-9 \cdot 1\end{array}$ & $\begin{array}{l}-1.75 \\
-1.4\end{array}$ & $\begin{array}{l}-14 \cdot 05 \\
-14 \cdot 7\end{array}$ & $\begin{array}{l}-5 \cdot 25 \\
-4 \cdot 10\end{array}$ \\
\hline
\end{tabular}

Again, potassium chloride causes aerobic glycolysis in the case of mannose ${ }^{2}$, which can form lactic acid anaerobically.

The following theory is put forward to explain the co-existence of aerobic glycolysis and increased respiration with glucose, as well as the sparing action of oxygen on the glycolysis of normal cells. Oxygen may be supposed so to affect the cell permeability as to set a limit to the rate at which glucose can reach the cell enzymes. Inhibition of the Pasteur effect consists in a removal of this limitation, so enabling more glucose to reach the intracellular enzymes. This increased permeability results in an increased rate of both respiration and lactic acid formation. 